E-ISSN. 2685-7650

Vol. 2 No. 1 (2020), pp $42-55$

DOI: https://doi.org/10.33366/jkn.v2i1.44

\title{
Kualitas Berita Pilkada Kota Malang di Media Daring
}

\author{
Kariman $^{1}$, Fathul Qorib ${ }^{2}$ \\ 1,2Program Studi Ilmu Komunikasi, Universitas Tribhuwana Tunggadewi \\ Email: fathul.indonesia@gmail.com
}

\begin{abstract}
The development of technology makes online media get a greater portion of readers than print media that were first born. Online media that rely on speed often violate journalistic code of ethics so it should be reviewed so that there is an improvement. This study aims to look at the quality of news on Regional Election (Pilkada) on Malangvoice.com. This study uses a qualitative method. The data source in this research are the news in Malangvoice.com online mass media related to Malang City Election News which was taken in June 2018. This media was chosen because it is one of the most widely read media in Malang Raya. The set of analysis units amounted to 15 Pilkada news in the voting month, namely June 2018. The news quality theory used in this study is in accordance with the Journalistic Code of Ethics, namely accuracy, balance, objectivity, concise, and actual. The results showed Malang Voice has advantages in the field of technical quality such as writing, the object of reporting, brevity and actuality. But Malang Voice has weaknesses in the quality of news content such as accuracy, objectivity and balance.
\end{abstract}

Keywords: News Quality, Malang City Election, Journalistic Code of Ethics, Malangvoice

\begin{abstract}
Abstrak: Perkembangan teknologi membuat media daring mendapatkan porsi pembaca yang lebih banyak dibandingkan media cetak yang lebih dulu lahir. Media daring yang mengandalkan kecepatan seringkali melanggar kode etik jurnalistik sehingga patut dikaji agar ada perbaikan. Penelitian ini bertujuan untuk melihat kualitas berita Pemilihan Kepala Daerah (Pilkada) di Malangvoice.com. Penelitian ini menggunakan metode kualitatif. Sumber data dalam penelitian ini adalah berita yang ada di media massa online Malangvoice.com terkait berita Pemilihan Kepala Daerah Kota Malang yang diambil pada Bulan Juni 2018. Media ini dipilih karena menjadi salah satu media yang paling banyak dibaca di Malang Raya. Unit analisis yang ditetapkan berjumlah 15 berita Pilkada pada bulan pencoblosan, yaitu Juni 2018. Teori kualitas berita yang digunakan dalam penelitian ini sesuai dengan Kode Etik Jurnalistik, yaitu akurasi, keberimbangan, obyektifitas, ringkas, dan aktual. Hasil penelitian menunjukkan Malang Voice memiliki kelebihan di bidang kualitas teknis seperti penulisan, obyek pemberitaan, keringkasan dan aktualitas. Tetapi Malang Voice memiliki kelemahan pada kualitas isi berita seperti akurasi, obyektifitas dan keberimbangan.
\end{abstract}

Kata kunci: Kualitas Berita, Pilkada Kota Malang, Kode Etik Jurnalistik, Malangvoice

\section{Pendahuluan}

Media massa merupakan sebuah sarana atau wadah yang digunakan oleh para pemilik media untuk menyampaikan informasi kepada khalayak atau masyarakat luas di suatu wilayah yang sebagian besar anonim (Imran, 2013). Selain itu media massa juga merupakan suatu alat yang bergerak di ruang publik sesuai dengan kepentingan pengguna atau konsumennya, yang berdasarkan kegiatan utamanya yaitu menghimpun, mengolah konten-konten simbolik dan partisipasi secara profesional (McQuail, 2017). Media massa dapat menyebarkan gagasan atau opini, komentar, hiburan, kebijakan publik, hingga pengetahuan ilmiah (Habibie, 2018).

Media massa digunakan untuk penyampaian informasi dari komunikator kepada khalayak dengan menggunakan alat-alat komunikasi mekanis, seperti surat kabar, radio, televisi, film, dan internet (Suryawati, 2011). Pengertian ini mengandung arti bahwa media massa hanyalah alat yang obyektif dan bebas nilai. Pengguna dari alat itu yang akan mengarahkan media massa 


\section{Jurnal Komunikasi Nusantara}

\section{E-ISSN. 2685-7650}

Vol. 2 No. 1 (2020), pp $42-55$

DOI: https://doi.org/10.33366/jkn.v2i1.44

menjadi alat yang independen atau berpihak ke perseorangan dan golongan. Karenanya media massa sulit bebas nilai dan bebas tekanan disebabkan ada batasan-batasan tertentu dalam aturan pemerintah maupun karena interaksi redaksi tidak selalu bisa obyektif (Fabriar, 2014; Susanto, 2017).

Dengan demikian media massa dalam ruang publik yang digunakan oleh masyarakat tidak hanya berperan dan berfungsi sebagai media informasi, namun memiliki fungsi dan kepentingan lain untuk mempengaruhi khalayaknya. Dengan adanya fungsi-fungsi tersebut yang kita rasakan saat ini, tentunya tidak lepas dari industri media massa yang saat ini banyak dipengaruhi oleh para pemilik modal yang juga agenda tersendiri. Bagaimanapun realitas yang dijadikan obyek liputan media massa, terutama berita politik, tidak pernah obyektif sehingga media massa juga disangsikan dapat memberitakan secara obyektif (Ahmad, 2016).

Menghadapi banyak agenda industri, kepentingan ekonomi dan politik, pekerja media juga akan berada di jalan yang ambigu. Bagi (Barus, 2010) inilah yang dinamakan sebagai sisi gelap bisnis berita di media massa. Karena itu penelitian terkait kualitas berita dari berbagai sisi yang sesuai dengan Kode Etik Jurnalistik menjadi penting karena media menjadi alat berbagai wacana bertarung, Hal itu dikemukakan oleh Antonio Gramsci yang mengkritik pemikiran Althusser yang menganggap media sebagai alat penguasa untuk melegitimasi kekuasaannya. Sebaliknya isi media massa adalah pertarungan wacana bukan hanya sekadar alat penguasa (Sobur, 2015).

Media massa memiliki sajian penting yang berguna bagi masyarakat secara luas, yaitu berita. Berita (news) merupakan suatu informasi dari suatu kejadian atau peristiwa yang terjadi di lingkungan sosial masyarakat. Berita dapat diartikan sebagai berita sebagai laporan peristiwa yang ditulis untuk media massa (Qorib, 2019). Menurutnya, konsep itu akan membatasi banyak laporan yang ditulis oleh orang lain yang bukan wartawan sebagai bukan bagian dari berita, termasuk Humas perusahaan yang menulis informasi tapi tidak ditujukan kepada media massa, juga bukan berita.

Media massa yang hadir dengan berbagai jenis dan juga kemasan yang berbeda-beda dengan tujuan untuk menarik perhatian dan minat konsumennya. Media cetak maupun elektronik telah membuat banyak terobosan sehingga dipercaya publik. Kini industri media massa kedatangan jenis media baru yang memiliki perbedaan signifikan dengan media sebelumnya. Media pendatang baru tersebut adalah media online atau media dalam jaringan (daring). Media daring merupakan media yang dalam penggunaanya menggunakan jaringan internet, baik dalam pengolahan informasi dan juga distribusi informasi kepada khayalak ramai.

Media daring sendiri bekerja dengan mengandalkan kecepatan yang dimiliki dalam menyampaikan informasi, karena media daring secara sistem, mengunakan website sebagai sarana untuk mendistribusikan berita kepada konsumenya (Juditha, 2013; Nurkinan, 2017). Selain itu media daring juga dapat di akses dengan menggunakan gawai dan memungkin semua konsumen dapat dengan mudah menerima informasi secara cepat. Seperti layaknya media massa lainya. Media siber juga memproduksi berita dalam berbagai topik seperti, politik, pemerintahan, sosial, ekonomi, budaya, pendidikan dan juga agama.

Data yang diperoleh dalam buku jurnal Dewan Pers Indonesia, jumlah perusahaan pers online atau cyber media hingga saat ini mencapai jumlah yang fantastis yaitu berjumlah 43.000 media siber, namun mirisnya hanya 130 media online yang terdata dewan pers (Depan Pers, 


\section{Jurnal Komunikasi Nusantara}

\section{E-ISSN. 2685-7650}

Vol. 2 No. 1 (2020), pp $42-55$

DOI: https://doi.org/10.33366/jkn.v2i1.44

2018; Pikiran Rakyat, 2018). Tempo pernah merilis berita bahwa "media daring sering dinilai tak serius" mengenai isi berita, antara akurasi dan kecepatan berita serta unsur berita lainya seperti nilai berita dan tata bahasa dalam penulisan berita yang baik dan benar (Tempo, 2016). Dalam media yang sama, dewan pers menerima 18 pengaduan terkait pers online yang tidak netral dalam melakukan pemberitaan Pilkada dan terindikasi menjadi alat kampanye.

Beragamnya media massa yang ada di Indonesia tentunya memiliki pengaruh terhadap pemerintahan dan juga politik di indonesia. Di indonesia terdapat pesta demokrasi yang terjadi setiap lima tahun sekali. Pesta demokrasi tersebut dapat terwujud dengan adanya, pemilihn presiden yang dikenal dengan (Pilpres) pemilihan gubernur, pemilihan bupati, wali kota yang juga di kenal dengan (Pilkada), serta pesta demokrasi terkait pemilihan Anggota DPR RI dan DPRD sebagai Fungsi Legsilatif dalam pemerintahan Indonesia yang dikenal dengan (Pileg).

Momen-momen pesta demokrasi kerap menjadi fokus media massa dalam pemberitaannya karena berkaitan dengan masyarakat luas dan calon pemimpin masyarakat. Hal itu termasuk Pilkada Kota Malang tahun 2018. Ada tiga calon kepala daerah yang berjuang merebut posisi Wali Kota, urutan pertama adalah Ya'qud Ananda Gudban (Partai Hanura) dan Achmad Wanedi (PDIP) yang diusung partai PDIP, Hanura, PAN, PPP, dan NasDem, nomor urut kedua M Anton (PKB) dan Syamsul Mahmud (Non Partai) diusung PKB, Gerindra, dan PKS, terakhir Sutiaji (Partai Demokrat) dan Sofyan Edi Jarwoko (Golkar) yang diusung Demokrat dan Golkar.

Pelaksanaan tahapan Pilkada Kota Malang tahun tersebut memiliki cerita yang berbeda karena dua calon tersandung kasus suap APBD-P tahun 2005, yaitu Ya'qud Ananda Gudban dan M Anton. Media massa yang mengetahui kasus tersebut pasti akan banyak memberitakan tentang pertarungan politik yang tidak imbang karena Sutiaji dan pasangannya bebas kampanye sedangkan dua lawan politiknya berada di penjara. Sehingga media massa harus berhati-hati karena publik dapat terpengaruh atas berbagai pemberitaan yang tidak mengikuti kaidah jurnalistik.

Akurasi dalam berita media massa tentunya menjadi tolok ukur yang sangat penting (Damayanti, 2016; Suwarno \& Suryawati, 2019). Karena poin tersebut dapat berpengaruh kepada tingkah laku dan wawasan khalayak sebagai pembaca informasi yang di sampaikan oleh media massa sebagai produsen dan distributor berita. Unsur-unsur dalam penulisan berita seperti $5 \mathrm{~W}+1 \mathrm{H}$ dan nilai berita juga menjadi poin penting yang wajib ada dalam sebuah berita. Selain itu fakta dan data serta aktualitas berita juga harus diperhatikan agar media massa dapat menjalankan fungsinya kepada publik. Tujuan utama dari penelitian ini adalah untuk mengetahui bagaimana pemberitaan di media online terkait Pilkada Kota Malang tersebut.

\section{Metode Penelitian}

Penelitian ini menggunakan metode kualitatif yang lebih condong pada pendeskripsian analisis secara detail serta mendalam. Menurut (Sutopo, 2010) penelitian kualitatif mengarah pada pendeskripsian secara rinci dan mendalam baik kondisi maupun proses, serta hubungan saling keterkaitannya mengenai hal-hal pokok yang ditemukan pada sasaran penelitian. Penelitian kualitatif juga bisa didefinisikan sebagai prosedur penelitian yang menghasilkan data deskriptif berupa kata-kata tertulis atau lisan dari orang-orang dan perilaku yang diamati (Moleong, 2012). 


\section{Jurnal Komunikasi Nusantara}

\section{E-ISSN. 2685-7650}

Vol. 2 No. 1 (2020), pp 42-55

DOI: https://doi.org/10.33366/jkn.v2i1.44

Sumber data dalam penelitian ini adalah berita yang ada di media massa online Malangvoice.com terkait berita Pemilihan Kepala Daerah Kota Malang yang diambil pada Bulan Juni 2018. Pemilihan berita pada bulan tersebut didasarkan pada pertimbangan akan banyaknya berita terkait pasangan calon yang akan berkompetisi dalam Pilkada Malang. Apalagi pelaksanaan Pilkada juga pada Bulan Juni sehingga media massa akan berlomba memproduksi berita terkait Pilkada untuk memuaskan keingintahuan pembaca.

Prosedur penentuan unit analisis dimodifikasi dari langkah-langkah disarankan oleh (Cresswell, 2007) sebagai berikut: 1) Menentukan bulan Juni sebagai basis umum berita Pilkada karena bulan ini Pilkada Malang akan berlangsung, 2) Mengumpulkan berita yang berhubungan dengan Pilkada, baik langsung maupun tidak langsung. 3) Melakukan reduksi obyek berita yang tidak berhubungan langsung dengan Pilkada sehingga lebih fokus dan terarah. 4) Melakukan analisis dan pengambilan kesimpulan.

Tabel 1. Unit analisis penelitian yang diambil dari Malang Voice

\begin{tabular}{|c|c|c|}
\hline No & Judul Berita dari Malang Voice & Tanggal Muat \\
\hline 1 & Kaum Difabel Jadi Perhatian Serius Sutiaji & 01 Juni 2018 \\
\hline 2 & Sutiaji-Sofyan Edi Fokus Cari Solusi Lindungi Anak dan Perempuan & 04 Juni 2018 \\
\hline 3 & Paslon Sae Komitmen Pertahankan Ruang Terbuka Hijau & 07 Juni 2018 \\
\hline 4 & $\begin{array}{l}\text { Gagasan Sutiaji Mengatasi Masalah Pendidikan Bagi Warga Kurang } \\
\text { Mampu }\end{array}$ & 10 Juni 2018 \\
\hline 5 & $\begin{array}{l}\text { Tegas, Wanedi Teken Ratusan Kontrak Politik untuk Realisasikan } 25 \\
\text { Aksi Menawan }\end{array}$ & 11 Juni 2018 \\
\hline 6 & Dukungan Terus Mengalir Untuk Sutiaji - Bung Edi & 12 Juni 2018 \\
\hline 7 & Injury Time, Peni Serukan Dukungan Untuk Sae & 12 Juni 2018 \\
\hline 8 & Lewat Regulasi, Menawan Canangkan Malang Anti Narkotika & 13 Juni 2018 \\
\hline 9 & $\begin{array}{l}\text { Paslon Sae Dapat Saran Berbagai Pihak Apabila Terpilih Memimpin } \\
\text { Kota Malang }\end{array}$ & 15 Juni 2018 \\
\hline 10 & Akbar Tanjung Tak Luput Dukung Sae Menangai Pilwali Kota Malang & 16 Juni 2018 \\
\hline 11 & Wanedi Komitmen Kembalikan Malang Jadi Barometer Musik & 16 Juni 2018 \\
\hline 12 & Rehabilitasi Pasar Belimbing Jadi Prioritas Paslon Sae & 18 Juni 2018 \\
\hline 13 & $\begin{array}{l}\text { Kembali Teken Kontrak Politik, Lima Komunitas Nyatakan Dukung } \\
\text { Menawan }\end{array}$ & 19 Juni 2018 \\
\hline 14 & $\begin{array}{l}\text { AHY Beri Dukungan Penuh Pasangan Khofifah - Emil dan Sae di } \\
\text { Pilkada } 2018\end{array}$ & 20 Juni 2018 \\
\hline 15 & Gelar Halal Bi Halal, Wanedi: Kemenangan Menawan di Depan Mata & 24 Juni 2018 \\
\hline
\end{tabular}




\section{Jurnal Komunikasi Nusantara}

\section{E-ISSN. 2685-7650}

Vol. 2 No. 1 (2020), pp 42-55

DOI: https://doi.org/10.33366/jkn.v2i1.44

\section{Hasil dan Pembahasan \\ Analisa dan Pembahasan}

Sesuai dengan teori yang dipakai oleh peneliti. Dalam buku Jurnalistik Teori Dan Praktik. (Budyatna 2012) . Menjelaskan bahwa mengenai syarat untuk mencapai kualitas berita yang baik dalam Kode Etik Jurnalistik (KEJ) pasal lima (5). Yang berbunyi "wartawan indonesia menyajikan berita secara berimbang dan adil, mengutamakan kecermatan dan ketepatan, serta tidak mencamnpurkan fakta dan opini wartawan. tulisan berinterpretasi dan opini wartawan harus menyertakan nama jelas penulisanya" tidak cukup dengan itu saja sebagai ukuran dalam menentukan kualitas berita. Pernyatan dalam kode etik tersebut dijabarkan dalam beberapa bentuk ukuran yakni, akurasi berita, keberimbangan berita, keobjektifan berita, keringkasan berita, dan aktualitas berita.

\section{a. Akurasi}

Akurasi merupakan sebuah ketepatan kecermatan dalam berita yang ditulis oleh seorang wartawan sebagai pelaku dalam penghimpunan, pengolah, sebuah informasi yang di dapatkan (Hansen, 2016; Maier, 2005). Akurasi dalam penulisan berita di media massa dapat dimaksudkan dalam bentuk akurasi penulisan kalimat, penulisan waktu, penulisan tempat, penulisan fakta, serta keakurasian penulisan antara judul dengan isi berita.

Akurasi dalam berita juga menjadi standar etik yang harus diterapkan di samping standar profesional maupun operasional yang harus di terapkan oleh wartawan meskipun dalam kenyataanya di lapangan sebuah akurasi dapat terganggu dengan adanya batas waktu atau tekanan dari perusahaan media. Sebagai contoh berita Malangvoice.com pada tanggal 11 Juni 2018 sebagai berikut:

Tegas, Wanedi Teken Ratusan Kontrak Politik untuk Realisasikan 25 Aksi Menawan

Pewarta

Muhammad Choirul

11 June 2018 11:03 PM

Calon Wakil Wali Kota Malang nomor urut 1, Ahmad Wanedi. (Muhammad Choirul)

MALANGVOICE - Pasangan Calon Wali Kota dan Wakil Wali Kota Malang nomor urut 1, Ya'qud Ananda Gudban - H Ahmad Wanedi, tak main-main dengan program 25 Aksi Menawan. Pasangan ini punya cara jitu untuk meyakinkan publik atas komitmen program itu dengan melakukan kontrak politik.

Calon Wakil Wali Kota Malang, H. Ahmad Wanedi, menegaskan bahwa sudah ratusan kontrak politik diteken, baik kepada masyarakat maupun orang perorang terkait 25 Aksi Menawan itu. Ini menunjukkan antusias tinggi dari warga dalam merespon program Menawan.

Seperti kontrak politik dengan pedagang Pasar Minggu yang ingin kembali ke Jalan Semeru, Wanedi mengaku jika sudah melakukan hal itu dan mendapat respon yang baik. "Beberapa sopir angkot dari berbagai jalur juga telah menandatangani kontrak politik dengan Paslon Menawan terkait dengan program angkot gratis serta komitmen agar angkot konvensional bisa tetap eksis," tandasnya.

\section{Akbar Tanjung Tak Luput Dukung Sae Menangi Pilwali Kota Malang}

Pewarta

Deny Rahmawan

16 June 2018 9:05 PM 


\section{Jurnal Komunikasi Nusantara}

E-ISSN. 2685-7650

Vol. 2 No. 1 (2020), pp 42-55

DOI: https://doi.org/10.33366/jkn.v2i1.44

MALANGVOICE - Politikus senior Partai Golkar, Akbar Tanjung, memberikan dukungan kepada paslon nomor urut 3 di Pilwali Kota Malang, Sutiaji - Sofyan Edi Jarwoko.

Akbar menyebut Sofyan Edi Jarwoko alias Bung Edi, yang merupakan Ketua DPD Partai Golkar Kota Malang itu cocok dampingi Sutiaji apabila terpilih menjadi pemimpin.

"Bung Edi itu sudah saatnya, karena masyarakat Kota Malang sudah banyak yang tahu rekam jejaknya. Sejak tahun 90 an, Bung Edi sudah aktif di Golkar," kata Akbar.

Akbar juga menyampaikan kepada Bung Edi, bahwa pemimpin itu harus adil, sabar dan mengayomi.

Sampai saat ini, tren popularitas pasangan calon (paslon) Sae sedang naik di atas dua rivalnya. Kenaikan popularitas dan elektabilitas dari hasil survei independen ini merupakan bukti bahwa public trust (kepercayaan masyarakat) untuk paslon Sae semakin meningkat.

“Insya Allah sukses. Semoga bisa membawa Malang menjadi bermartabat, Malang yang Sae,” ujar Wakil Dewan Kehormatan Partai Golkar itu.

Sementara itu, Bung Edi menanggapi naiknya popularitas tim Sae dengan landai dan tetap bersyukur, karena tren ini mesti dijaga dengan terus bekerja keras. Kelengahan merasa menang ini bisa membawa lupa diri, sehingga hasil akhir pada pencoblosan Rabu, 27 Juni 2018 menjadi anti klimaks.

Dua berita di atas dapat dianalisis berdasarkan akurasinya, yaitu ketepatan penulisan, ketepatan waktu, tempat, dan komponen lainnya. Tekns penulisan merupakan langkah pertama yang dilakukan oleh seorang jurnalis dalam melakukan penyampaian berita kepada khalayak ramai. Penulisan menjadi ukuran penting dalam sebuah akurasi berita, karenanya dengan menggunakan penulisan yang tepat dan benar tanpa ada kesalahan dalam penulisan berita membuat berita mudah untuk di mengerti oleh para pembacanya. Namun demikian dari kedua contoh diatas dapat dilihat bahwa dalam penulisanya memiliki kekurangan dalam ketepatanya.

Kesalahan tersebut dapat dilihat pada berita pertama yakni di bagian paragraf pertama pada kata "Pasangan Calon" kata seperti ini hendakanya diberi keterangan akronim atau kata sambung dari kedua kata tersebut dengan di tulis menjadi "Pasangan Calon (Paslon)", hal ini tersebut dilakukan untuk memudahkan pembaca pada pargraf berikutnya namun dengan catatan dalam pargraf berikutnya tidak boleh terjadi pengulangan penulisan yang sama, apabila telah di jadikan akronim maka dalam menulisnya dapat di tulis secara langsung menjadi kata "Paslon" tanpa kepanjangan yaitu " pasangan calon".

Kesalahan berikutnya terdapat pada paragraf ketiga pada kata "paslon" kata ini salah karena pada paragraf pertama kata " pasangan calon tidak di jadikan akronim sehingga penulisan secara langsung pada pargraf tiga tidak di perbolehkan karena membuat pembaca binggung terlebih bagi konsumen yang baru memulai atau orang yang betul-betul awam terhadap dunia penulisan jurnalistik. kesalahan ini menujukan tidak adanya konsistensi penulisan. Kesalahan lainnya ialah terdapat pada paragraf kelima, yakni, pada kata "PDIP" kata ini merupakan singkatan dari Partai Demokrasi Indonesia Perjuangan, seharusnya jika penulisan seperti ini hendaknya ditulis secara lengkap terlebih dahulu dengan menggunakn huruf besar pada lawan katanya kemudian diberikan tanda kurung dalam singkatanya seperti berikut "Partai Demokrasi Indonesia Perjuangan (PDIP).

Kesalahan berikutnya juga terjadi pada berita kedua, berita pada tanggal 16 Juni 2018. Kesalahan tersebut terletak pada kata yang bergaris bawah di paragraf pertama, 


\section{Jurnal Komunikasi Nusantara}

\section{E-ISSN. 2685-7650}

Vol. 2 No. 1 (2020), pp 42-55

DOI: https://doi.org/10.33366/jkn.v2i1.44

paragraf kedua dan paragraf ketiga, kata tersebut diantaranya, "Golkar, DPD, pasangan palon (paslon)" pada kata pertama Golkar, seharusnya di tulis terlebih dahulu secara lengkap mengenai kepanjanganya sebelum disingkat sehingga tidak membuat pembaca salah mengartikan, begitu juga selanjutnya pada kata "DPD" hendaknya di tulis secara detail mengenai kata lengkap dari DPD, seharusnya pada kedua kata tersebut di tulis menjadi “ Golongan Karya (Golkar) dan juga Dewan Pimpinan Daerah (DPD)" kedua hal itu dilakukan untuk memberi pengetahuan bagi pembaca yang tidak paham mengenai singkatan dan juga memudahkan mereka dalam memahami informasi. Kemudian pada kata ketiga kesalahanya ialah tidak menggunakan huruf besar pada penulisanya, kata tersebut harsunya di tulis menjadi "Pasangan Calon (Paslon)" penulisan demikian dilakukan karena kata tersebut menunjukan obyek atau benda dalam hal ini di artikan pasangan nomor urut tiga yaitu Sutiaji dan Sofyan Edi Jarwoko.

Selain aspek teknis di atas, akurasi di bidang kesesuaian judul dan isi juga banyak bermasalah. Pada berita yang berjudul : "Tegas, Wanedi Teken Ratusan Kontrak Politik Untuk Realisasikan 25 Aksi Menawan” menjelakan bahwa Wanedi 'tegas' dengan melaksankan ratusan kontrak politik untuk merealisaskan program 25 aksi Menawan. Kata "tegas" di awal kalimat menunjukan bahwa wartawan dalam menulis judul berita tersebut ingin mengonstruksi emosional pembaca melalui menggambarkan bahwa Wanedi merupakan sosok yang tegas. Di sisi lain pada isi beritanya, hanya disampaikan satu kontrak politik yang terdapat pada paragraf ketiga:

"Seperti kontrak politik dengan pedagang Pasar Minggu yang ingin kembali ke Jalan Semeru, Wanedi mengaku jika sudah melakukan hal itu dan mendapat respon yang baik."

Paragraf tersebut hanya memaparkan satu kontrak politik yakni dengan pedagang pasar, selain itu dalam isi berita tidak ada dokumen jumlah komunitas atau jumlah pihak yang telah bekerja atau 'meneken kontrak politik' dengan Wanedi. Berita tersebut tidak terdapat nilai akurasi antara judul dengan isi berita. Hal yang sama juga terjadi pada berita kedua. Pada berita tersebut terdapat judul sebagai berikut:

"Akbar Tanjung Tak Luput Dukung Sae menangi Pilwali Kota Malang”

Judul berita tersebut menunjukan bahwa Akbar Tanjung yang 'tak luput' turut serta dalam memberikan dukunganya kepada pasangan Sae. Kata "tak luput" memberi arti adanya banyak dukungan kepada pasangan Sae, sampai-sampai Akbar Tanjung juga mendukungnya. Tapi dalam pemberitaan tidak ada penjelasan tersebut, wartawan tidak proporsional dalam menulis judul berita dan isinya. Di bagian lain berita hanya menyampaikan ungkapan dari Akbar Tanjung bahwa Bung Edi sudah saatnya memimpin Kota Malang karena sejak tahun 90an Bung Edi sudah aktif di Partai Golkar. selain itu Akbar Tanjung juga menyampaikan pesanya kepada pasangan Sae agar tetap adil dan berharap agar sukses di Pilkada Kota Malang. Dengan demikian judul berita tersebut tidak sesuai. 


\section{Jurnal Komunikasi Nusantara}

\section{E-ISSN. 2685-7650}

Vol. 2 No. 1 (2020), pp 42-55

DOI: https://doi.org/10.33366/jkn.v2i1.44

\section{b. Berimbang}

Berimbang merupakan bagian penting dalam sebuah pemberitaan oleh media massa dan patut diperjuangkan oleh wartawan (Richards \& King, 2020). Berimbang dalam dunia jurnalistik disebut juga dengan istilah cover both sides di mana dalam sebuah berita tidak diperbolehkan untuk menghilangkan unsur-unsur fakta yang sebenarnya dan juga tidak di perbolehkan untuk menambah-nambahkan fakta yang menekan kepada sebelah pihak pada suatu kasus pemberitaan. Dalam arti lain keseimbangan dimaksudkan infiormasi yang diberitkan memiliki poisi jumlah yang sama terhdap semua pihak yang terlibat, serta tidak memasukan banyak opini seorang jurnalis atau wartawan. Sebagai contoh Adapaun berita yang tidak berimbang pada Malangvoice.com pada tanggal 24 Juni 2018.

\section{Gelar Halal Bi Halal, Wanedi: Kemenangan Menawan di Depan Mata}

Pewarta

\section{Muhammad Choirul}

24 June 2018 11:16 PM

MALANGVOICE - Momen Hari Raya Idul Fitri 1439 Hijriyah tahun ini dimanfaatkan dengan baik oleh Calon Wakil Wali Kota Malang, H. Ahmad Wanedi untuk halal bi halal serta bersilaturahmi dengan para tokoh masyarakat hingga partai politik.

"Dari survei yang dilakukan oleh internal dari tim sukses, Paslon Menawan unggul atas paslon lain di Pilkada Malang dengan raihan suara yang cukup signifikan"

Contoh berita di atas tidak memiliki keberimbangan dalam penulisanya karena berita di atas di tulis dengan memojokan pihak lain dan ditulis dengan memasukkan opini wartawan. Kalimat tersebut mengandung unsur klaim dari salah satu pihak yaitu pihak pasangan Calon Menawan nomor urut satu, yang menyatakan bahwa survei internal mereka unggul dari kedua pesaingnya yakni pasangan Asik nomor urut dua dan pasangan Sae nomor urut tiga.

Dengan klaim demikian, seharusnya pihak media melalui jurnalisnya mencari informasi tentang survei yang sah dari lembaga survei mengenai hasil survei ketiga pasangan agar dapat dilihat hasil sesungguhnya agar sehingga terkesan meremehkan pasangan lain. Selain itu dengan pernyatan dan tidak adanya berita mengenai hasil survei yang sah maka, Malangvoice.com pada dasarnya tidak menerapkan prinsip cover both sides atau prinsip keberimbangan suatu berita. Pihak yang berhubungan tidak diletakan dalam posisi yang sama sehingga terjadi penggiringan opini yang tidak fair.

Kemudian tidak berimbangnya berita tersebut juga terlihat adari pernyataan yang ditulis oleh wartawan pada paragraf ketujuh. Adapaun cuplikan teksnya sebagai berikut.

"Jika dilihat dari susunan partai pengusung saja, suara kita sudah hampir mendekati 50 persen dari suara masyarakat yang memiliki hak pilih. Sehingga, dengan solidnya partai politik pengusung Paslon Menawan bisa mengantarkan kita kepada kemenangan,"

Dilihat dari cuplikan tersebut, maka semakin memperkuat bahwa berta di atas tidak seimbang dalam memposisikan kewenangan pihak yang terkait, karena masih terdapat banyak kalim dan opini yang dituliskan oleh jurnalis dan tidak melakukan disiplin 


\section{Jurnal Komunikasi Nusantara}

\section{E-ISSN. 2685-7650}

Vol. 2 No. 1 (2020), pp 42-55

DOI: https://doi.org/10.33366/jkn.v2i1.44

verifikasi kepada pihak yang lain.pada kalimat diatas yang berbunyi "Jika dilihat daris susunan pengsusung saja suara kita sudah hampir mendekati 50 persen dari suara masyarakat yang memiliki hak pilih" kalimat tersebut merupakan klaim yang seharusnya dilakukan verifikasi atau crocscheck oleh pihak media dengan memberitakan jumlah real pendukung Pasangan Menawan serta memberitakan jumlah total daftar pemilih tetap pemilu Kota Malang. Selain itu kalimat pada kutipan tersebut juga terkesan mengecilkan jumlah pemilih tetap Kota Malang dan hanya direpresentasikan dengan jumlah pendukungnya.

Selanjutnya jika ditinjau dari sisi elemen berita yang dijelaskan oleh (Kovach \& Rosenstiel, 2006) pada bagian kedua yakni wartawan harus loyal kepada warga (Citizens). Kovach mengatakan bahwa dalam bisnis media terdapat segitiga yang harus diperhatikan yakni, segi pertama harus memperhatikan audience atau pemirsa, kedua harus memperhatikan pemasangan iklan, ketiga memperhatikan masyarakat. Dari keterangan tersebut maka dapat ditarik kesimpulan bahwa media massa dalam berita di atas melupakan dua faktor yaitu pada sisi pemirsa atau audience dan pada sisi masyarakat. Kedua sisi ini terabaikan oleh media karena dalam pemberitaannya media tidak menggali informasi secara mendalam tidak melakukan verifikasi agar pembaca tidak tersesat.

\section{c. Objektivitas.}

Objektifitas merupakan sebuah sikap dan sifat yang harus dimiliki oleh seorang wartawan dalam melaksanakan tugasnya untuk menghimpun informasi dari lapangan. Objektifitas dan subjektifitas yang dimiliki oleh seorang wartawan akan sangat mempengaruhi isi pemberitaan. Meskipun dalam sisi lain media memiliki kepentingan bisnis yang terkadang menekan wartawan untuk melupakan dan tidak menggunakan sifat objetifnya, tetapi hal itu tidak boleh dilakukan karena melanggar kode etik.

Mitchel V. Charnley dalam (Romly, 2018) mengatakan berita yang objektif adalah berita atau laporan mengenai laporan suatu fakta tanpa pandangan berat sebelah atau bias yang berarti laporan bersifat jujur. Yang dimaksud dengan objektifitas kuantitas ialah objektifitas dalam kadar jumlah, seberapa banyak objektifitas itu ada dalam media massa mengenai suatu pemberitaan. Kemudian dari objektifitas kualitas ialah objektifitas secara nilai isi pemaparan yang disamapikan oleh wartawan memiliki nilai kebenaran atau tidak, dalam arti lain tidak terdapat opini wartawan.

Dari pemaparan tersebut Malangvoice.com memiliki berita yang tidak objektif secara kuantitas berita, di Pilkada Kota Malang terdapat tiga calon pasangan yang ikut serta dalam kontestasi politik, namun dalam pemberitaan kampanyenya pada bulan juni 2018 hanya terdapat 23 berita kampanye dari kedua pasangan calon yakni, pasangan calon Menawan nomor urut satu sebanyak 10 berita dan pasangan calon Sae nomor urut tiga Yakni, 13 berita. Secara kuantitas maka dapat dilihat berita tersebut lebih banyak memberitakan pasangan calon Sae nomor urut tiga. Sementara pasangan Asik dari kubu petahan nomor urut dua, tidak terdapat berita kampanyenya. Sehingga dapat dikatakan bahwa malangvoice.com secara kuantitas tidak obyektif.

Malangvoice.com kurang memiliki berita yang objektif karena dalam pemberitaanya media massa memasukan opini penulis atau wartawan dengan kata dan kalimat yang 


\section{Jurnal Komunikasi Nusantara}

\section{E-ISSN. 2685-7650}

Vol. 2 No. 1 (2020), pp 42-55

DOI: https://doi.org/10.33366/jkn.v2i1.44

subjektif kepada sebalah pihak serta tidak melakukan verifikasi atau pembuktian nilai kebenaran secara utuh. Sebagai contoh cuplikan teks berita Malangvoice.com yang tidak objektif pada tanggal 11 Juni 2018, sebagai berikut:

\section{Tegas, Wanedi Teken Ratusan Kontrak Politik untuk Realisasikan 25 Aksi Menawan}

Pewarta

Muhammad Choirul

11 June 2018 11:03 PM

MALANGVOICE - Pasangan Calon Wali Kota dan Wakil Wali Kota Malang nomor urut 1, Ya'qud Ananda Gudban - H Ahmad Wanedi, tak main-main dengan program 25 Aksi Menawan. Pasangan ini punya cara jitu untuk meyakinkan publik atas komitmen program itu dengan melakukan kontrak politik.

Judul berita di atas menunjukan kalimat yang memihak dan konstruktif terhadap sosok Wanedi. Pada kata "tegas" mengonstruksikan kepada pembaca bahwa Wanedi merupakan sosok yang tegas dengan ratusan kontrak yang diteken dengan para pendukung. Kemudian selanjutnya pada paragraf pertama terdapat kalimat opini penulis yang di garis bawahi oleh peneliti, yang dicuplik sebagai berikut:

"Pasangan Calon Wali Kota dan Wakil Wali Kota Malang nomor urut 1, Ya'qud Ananda Gudban - H Ahmad Wanedi, tak main-main dengan program 25 Aksi Menawan."

Pada kalimat tersebut, pada kata "tak main-main" memiliki unsur kalimat dari seorang wartawan dalam menulis berita. Wartawan mengklaim bahwa Wanedi tidak hanya sekedar membuat program namun telah direalisasikan dalam kata lain wartawan menulis opini dengan melebih-lebihkan (hiperbola) dan mencoba untuk mnengubah pikiran pembaca untuk meyakini Wanedi adalah sosok yang tegas dan serius terhadap janjinya. Selain itu sebagai pada paragraf berikutnya terdapat pernyataan yang ditulis wartawan dengan tidak melakukan verifikasi :

"Calon Wakil Wali Kota Malang, H. Ahmad Wanedi, menegaskan bahwa sudah ratusan kontrak politik diteken, baik kepada masyarakat maupun orang perorang terkait 25 Aksi Menawan itu. Ini menunjukkan antusias tinggi dari warga dalam merespon program Menawan"

Kalimat tersebut menyatakan bahwa Wanedi telah melakukan ratusan kontrak politik dengan berbagai elemen, dan mendapat respon yang baik dari warga, namun secara objektivitas wartawan tidak melakukan verifikasi kepada elemen-elemen pendukung Wanedi, baik komunitas maupun warga. Wartawan dalam pemberitaannya tidak memberitakan respon dari warga dan juga tidak menyertakan dokumen jumlah kontrak poilitik yang diklaim ratusan telah diteken. Secara kualitas obyektifitas malangvoice.com pada berita Pilkada tidak memiliki obyektifitas yang baik.

\section{d. Ringkas dan Jelas}

Penulisan berita yang ringkas dan jelas merupakan bagian yang sangat penting dan harus dijaga oleh wartawan dan juga medianya. Karena dapat mempengaruhi kepuasan dan tingkat pemahaman pengunjung terhadap suatu topik pemberitaan. Ringkas dan jelas dalam penulisan berita dimaksudkan dalam penulisan kutipan kalimat langsung dari narasumber yang tidak berbelit-belit serta menggunakan bahasa dan kalimat yang mudah dipahami oleh pembaca. Pada berita malangvoice.com dalam penulisan kutipan langsung 


\section{Jurnal Komunikasi Nusantara}

\section{E-ISSN. 2685-7650}

Vol. 2 No. 1 (2020), pp 42-55

DOI: https://doi.org/10.33366/jkn.v2i1.44

yang dilakukan oleh wartawan pada umumnya memiliki kalimat dan menggunakan katakata yang jelas dan mudah dimengerti oleh pembaca, adapun contoh berita tanggal 1 Juni 2018 di media Malangvoice.com yang ringkas dan jelas sebagai berikut:

\section{Kaum Difabel Jadi Perhatian Serius Sutiaji}

Pewarta

Deny Rahmawan

1 June 2018 12:35 PM

MALANGVOICE - Keberadaan kaum difabel di Kota Malang bakal serius diperhatikan paslon Sae. Menurut Calon Wali Kota Malang dari nomor urut 3, Sutiaji, kaum difabel adalah bagian dari warga Kota Malang yang memiliki kesetaraan hak dan kewajiban. Harus tidak ada diskriminasi.

Berita di atas menjelaskan terkait dengan kaum difabel di kota Malang yang akan menjadi perhatian khusus pasangan calon Sutiaji dan Sofyan Edi Jarwoko. Berita tersebut mudah dipahami dan ringkas. Lihat kelanjutan berita tersebut di bawah ini :

"Karena itu kewajiban pemerintah untuk menyiapkan sarana dan prasarana bagi penyandang difabel. Pemerintah bisa menggadeng kalangan swasta dan pengusaha untuk memberdayakan kaum difabel," katanya.

"Sampai saat ini sudah ada program pengembangan Usaha Kesejahteraan Sosial (UKS), pelatihan jahit, memijat bagi difabel netra, dan penambahan gizi untuk menghadirkan kemandirian ekonomi pada difabel, namun itu belum cukup, "lanjutnya.

Kalimat tersebut menggunakan kata-kata yang mudah dipahami dan tidak menggunakan bahasa yang berbelit-belit. Dimana maksud dari kalimat paragraf ketiga ialah, Sutiaji menjelaskan bahwa menyiapkan sarana dan prasarana bagi penyandang difabel merupakan kewajiban pemerintah dengan mengandeng kalangan swasta, dan pengusaha untuk memberdayakan kaum difabel. Kemudian pada kutipan kedua menjelaskan mengenai Usaha Kesejahteraan Sosial yang sudah ada di kota malang untuk kaum difabel, namun menurut Sutiaji itu saja belum cukup.

\section{e. Aktualitas.}

Aktualitas dalam sebuah berita menjadi faktor yang sangat penting untuk menentukan suatu kualitas berita, karena berhubungan dengan kepuasan konsumen yang membacanya. Aktualitas bisa diartikan sebagai pembaruan berita dari satu kasus atau topik berita yang terjadi di lapangan, hingga berita itu benar-benar jelas serta sampai tahap akhir suatu kasus yang diberitakan terus-menerus. Headline dan halaman muka dari suatu media pasti menunjukkan aktualitas berita karena menjadi salah satu unsur paling penting dalam kualitas berita (Fitriah \& El'Arsya, 2011; Sari, 2015).

Dalam penelitian yang dilakukan di media malangvoice.com, ada dua hasil dari aktualitas berita terkait berita Pilkada di Kota Malang. Aktualitas yang pertama ialah aktualitas secara umum dalam topik berita Pilkada tersebut, kedua adalah aktualitas secara khusus dalam satu judul berita yang berkaitan dengan isi berita. 


\section{Jurnal Komunikasi Nusantara}

E-ISSN. 2685-7650

Vol. 2 No. 1 (2020), pp 42-55

DOI: https://doi.org/10.33366/jkn.v2i1.44

\section{Tegas, Wanedi Teken Ratusan Kontrak Politik untuk Realisasikan 25 Aksi Menawan}

Pewarta

Muhammad Choirul

11 June 2018 11:03 PM

MALANGVOICE - Pasangan Calon Wali Kota dan Wakil Wali Kota Malang nomor urut 1, Ya'qud Ananda Gudban - H Ahmad Wanedi, tak main-main dengan program 25 Aksi Menawan. Pasangan ini punya cara jitu untuk meyakinkan publik atas komitmen program itu dengan melakukan kontrak politik.

\section{Akbar Tanjung Tak Luput Dukung Sae Menangi Pilwali Kota Malang}

Pewarta

Deny Rahmawan

16 June 2018 9:05 PM

MALANGVOICE - Politikus senior Partai Golkar, Akbar Tanjung, memberikan dukungan kepada paslon nomor urut 3 di Pilwali Kota Malang, Sutiaji - Sofyan Edi Jarwoko.

Aktualitas berita secara garis besar topik berita yakni Pilkada di Malangvoice.com sudah tepat dan dimiliki oleh media tersebut, dengan adanya berita-berita kampanye oleh masing-masing pasangan calon yang di tulis oleh wartawan. Berita di atas adalah dua berita kampanye dari dua pasangan calaon, mengenai dukungan dan komitmen pendukung dan pasangan calon. Namun aktualitas secara khusus dalam satu judul berita tidak dimiliki oleh Malangvoice.com sebagai media daring, karena terdapat beberapa kesalahan yang harusnya diberitakan kembali, seperti pada kedua berita di atas yang kalimatnya diberi garis bawah dan dicuplik oleh peneliti sebagai berikut.

"Beberapa sopir angkot dari berbagai jalur juga telah menandatangani kontrak politik dengan Paslon Menawan terkait dengan program angkot gratis serta komitmen agar angkot konvensional bisa tetap eksis, " tandasnya.

Sampai saat ini, tren popularitas pasangan calon (paslon) Sae sedang naik di atas dua rivalnya. Kenaikan popularitas dan elektabilitas dari hasil survei independen ini merupakan bukti bahwa public trust (kepercayaan masyarakat) untuk paslon Sae semakin meningkat."

Pada kutipan pertama ditulis bahwa terdapat beberapa sopir angkot dari berbagi jalur yang telah menandatangi kontrak politik dengan pasangan Wanedi, dengan komitmen program angkot gratis. Seharusnya wartawan dan media memberitakan kapan adanya kontrak yang ditandangai oleh para sopir, serta berapa banyak sopir yang ikut gabung dalam kontrak politik. Dalam tulisan tersebut tidak disertakan waktu kapan para sopir melakukan kontrak politik tersebut. Pada kutipan kedua menjelaskan mengenai popularitas dan elektabilitas pasangan Sae yang semakin baik oleh lembaga survei independen, namun dalam kenyataanya malangvoice.com tidak memberikan keterangan terbaru mengenai bukti dari lembaga survei independen yang dikalim oleh pihak calon. Sehingga pada kedua berita diatas tidak memiliki aktualitas berita karena tidak terdapat pemberitaan terbaru dan penjelasan selanjutnya. 


\section{Jurnal Komunikasi Nusantara}

\section{E-ISSN. 2685-7650}

Vol. 2 No. 1 (2020), pp 42-55

DOI: https://doi.org/10.33366/jkn.v2i1.44

\section{Kesimpulan}

Kesimpulan dari hasil analisis di atas diketahui bahwa Malangvoice.com memiliki kualitas berita yang baik pada banyak aspek teknis pemberitaan, tapi kurang baik pada semua kualitas isi. Berita Malang Voice cukup baik ketika menguraikan akurasi tempat, subyek dan obyek berita, keterangan tempat dan waktu, dan penulisan berita jelas serta ringkas. Sedangkan pada aspek disiplin informasi yang merupakan bagian dari akurasi isi tidak dilakukan oleh Malang Voice, termasuk obyektifitas dan keberimbangan. Karena Malang Voice sering menggunakan satu narasumber dan merekam apa adanya informasi dari narasumber tanpa melakukan klarifikasi ke banyak pihak agar beritanya obyektif.

Penelitian ini sendiri memiliki kekurangan karena tidak memuat seluruh berita Pilkada maupun seluruh berita umum yang ada di kedua media. Penelitian lebih lanjut perlu dilakukan pada berita Pilkada pada tahun berikutnya sehingga didapatkan data yang lebih komprehensif sehingga dapat menggambarkan kualitas berita Malang Voice. Penelitian tentang kualitas berita di media lainnya juga perlu dilakukan, karena selain Malang Voice, masih banyak media lain yang setiap hari menyajikan konten berita bagi warga Kota Malang dan sekitarnya.

\section{Daftar Pustaka}

Ahmad, N. (2016). Media Massa, Kepentingan Publik dan Kekerasan Atas Nama Agama. Millah, XI(2), 351-378. https://doi.org/10.20885/millah.volxi.iss2.art2

Barus, S. W. (2010). Jurnalistik: Petunjuk Teknis Menulis Berita. Jakarta: Erlangga.

Cresswell, J. C. (2007). Qualitative Inquiry and Research Design: Choosing Among Five Approac. California: SAGE Publication, Inc.

Damayanti. (2016). Perbandingan Akurasi Media Online dalam Berita "Brexit" pada Empat Portal Berita di Indonesia. Prosiding: Akselersi Pembangunan Masyarakat Lokal Melalui Komunikasi Dan Teknologi Informasi, 302-312. Retrieved from http://jurnal.fisip.unila.ac.id/index.php/prosidingkom/issue/view/22/showToc

Depan Pers. (2018). Progam Pendataan Menjadi Ujung Tombak. Retrieved April 30, 2020, from dewanpers.org website: https://dewanpers.or.id/berita/detail/995/Progam-PendataanMenjadi-Ujung-Tombak

Fabriar, S. R. (2014). Etika Media Massa Era Global. An-Nida: Jurnal Komunikasi Islam, 6(1), 70-85.

Fitriah, M., \& El'Arsya, F. (2011). Berita Utama Surat Kabar Lokal di Bogor Studi Analisis Isi pada Jurnal Bogor dan Radar Bogor. Jurnal Komunikasi Pembangunan, 9(1), 11-19.

Habibie, D. K. (2018). Dwi Fungsi Media Massa. Interaksi: Jurnal Ilmu Komunikasi, 7(2), 79. https://doi.org/10.14710/interaksi.7.2.79-86

Hansen, A. (2016). The changing uses of accuracy in science communication. Public Understanding of Science, 25(7), 760-774. https://doi.org/10.1177/0963662516636303

Imran, H. A. (2013). Media Massa, Khalayak Media, The Audience Theory, Efek Isi Media dan Fenomena Diskursif. Jurnal Studi Komunikasi Dan Media, 16(1), 47. https://doi.org/10.31445/jskm.2012.160103

Juditha, C. (2013). News Accuracy in Online Journalism (News of Alleged Corruption The Constitutional Court in Detiknews). Jurnal Pekommas, 16(3), 145-154. Retrieved from https://media.neliti.com/media/publications/222363-akurasi-berita-dalam-jurnalisme- 


\section{Jurnal Komunikasi Nusantara}

\section{E-ISSN. 2685-7650}

Vol. 2 No. 1 (2020), pp 42-55

DOI: https://doi.org/10.33366/jkn.v2i1.44

online-k.pdf

Kovach, B., \& Rosenstiel, T. (2006). Sembilan Elemen Jurnalisme. Jakarta: Pantau.

Maier, S. R. (2005). Accuracy matters: A cross-market assessment of newspaper error and credibility. Journalism and Mass Communication Quarterly, 82(3), 533-551. https://doi.org/10.1177/107769900508200304

McQuail, D. (2017). Mass Communications Theory (6th Editio). London: SAGE Publication Ltd.

Moleong, L. J. (2012). Metodologi Penelitian Kualitatif. Bandung: Remaja Rosdakarya.

Nurkinan. (2017). Dampak Media Online Terhadap Perkembangan Media Konvensional. Jurnal Politikom Indonesiana, 2(2), 28-42. Retrieved from https://journal.unsika.ac.id/index.php/politikomindonesiana/article/download/962/792

Pikiran Rakyat. (2018). Media Online Sebagai Filter Berita Hoaks - Pikiran-Rakyat.com. Retrieved April 30, 2020, from pikiran-rakyat.com website: https://www.pikiranrakyat.com/advertorial/pr-01296926/media-online-sebagai-filter-berita-hoaks-424146

Qorib, F. (2019). Teknik Reportase dan Penulisan Berita. Malang: Intrans Publishing.

Richards, T., \& King, B. (2020). An Alternative to the Fighting Frame in News Reporting. Cannadian Journal of Communication, 25(4), 1-11.

Romly, A. S. (2018). Jurnalistik Online. Bandung: Nuansa Cendekia.

Sari, F. M. (2015). Komparasi Nilai Berita Tayangan Infotainment Insert di Trans TV dengan Intens di RCTI. Jurnal Visi Komunikasi, 14(2), 152-166.

Sobur, A. (2015). Analisis Teks Media. Bandung: Remaja Rosdakarya.

Suryawati, I. (2011). Jurnalistik: Suatu Pengantar. Bogor: Ghalia Indonesia.

Susanto, E. H. (2017). Media Massa, Pemerintah dan Pemilik Modal. Jurnal ASPIKOM, 1(6), 477-484. https://doi.org/10.24329/aspikom.v1i6.53

Sutopo, H. (2010). Metode Penelitian Kualitatif. Surakarta: UNS Pers.

Suwarno, \& Suryawati, I. (2019). Akurasi Berita Bencana Di Media Online ( Analisis Isi Berita Bencana Lombok Dan Bencana Donggala-Palu ) (Analysis of News Content Between Lombok Disaster and Donggala-Palu Disaster ). Jurnal Perspektif Komunikasi, 3(2), 5970 .

Tempo. (2016). Jurnalisme Online Sering Dinilai Tak Serius - Nasional Tempo.co. Retrieved April 30, 2020, from Tempo.co website: https://nasional.tempo.co/read/466520/jurnalisme-online-sering-dinilai-tak-serius. 